\title{
Adaptive increase in phytate digestibility by phosphorus-deprived rats and the relationship of intestinal phytase $(E C$ 3.1.3.8) and alkaline phosphatase $(E C 3.1 .3 .1)$ to phytate utilization
}

\author{
BY ROBERT J. MOORE* AND TRYGVE L. VEUM† \\ 110 Animal Science Research Center, University of Missouri, Columbia, \\ Missouri 65211, USA
}

(Received 1 June 1982-Accepted 2 September 1982)

1. The effects of phosphorus deprivation on phytate digestibility, phosphorus utilization and intestinal phytase $(E C$ 3.1.3.8) and alkaline phosphatase $(E C$ 3.1.3.1) in rats were investigated.

2. $\mathrm{P}$ deprivation was achieved by giving rats a diet containing $3 \mathrm{~g} \mathrm{P} / \mathrm{kg}$ and resulted in hypophosphataemia, hypercalcaemia, hypercalciuria, and lower levels of $\mathbf{P}$ absorbed and retained, and calcium retained.

3 . Rats adapted to $\mathbf{P}$ deprivation by increasing the digestion of total dietary-P and phytate-P.

4. Levels of intestinal alkaline phosphatase and alkaline phytase were not different between the two treatment groups.

5. P deprivation in the rats given the marginal-P diet may be a result of a lower absorption of total dietary-P or increased absorption of inositol phosphates formed during the enzymic hydrolysis of phytate which are not readily utilized by the rat.

6. These results suggest that intestinal phytase and alkaline phosphatase do not play a role in the adaptive increase in phytate digestibility by rats given marginal-P diets. The adaptation may result from enhanced phytase or alkaline phosphatase synthesis by the gastrointestinal microflora stimulated by a lower level of $\mathrm{P}$ in the digesta.

The predominant form of phosphorus in cereal grains and oilseed meals is inositol hexaphosphate (phytate) (Lolas et al. 1976). Even though phytate contributes a major portion of $\mathrm{P}$ to the diets of non-ruminants, the mineral is mostly unavailable to these animals (Taylor, 1980). Phytate also interferes with trace mineral and calcium utilization (Erdman, 1979; Nahapetian \& Young, 1980).

The bio-availability of $\mathrm{P}$ in phytate depends to a large extent on the level of inorganic-P in the diet. Moore \& Veum (1982) found that phytate-P was more available to rats given diets low in inorganic-P than from diets with supplements of $P$.

The mechanism by which phytate digestibility is increased in rats given low-P diets is unknown but may be related to the activity of phytase $(E C 3.1 .3 .8)$ and alkaline phosphatase (EC 3.1.3.1) present in rat intestine (Pileggi, 1959; Davies \& Flett, 1978). Phosphate transport from the intestine is stimulated by low dietary P levels in chicks (Fox et al. 1981), rats (Lee et al. 1979) and pigs (Fox \& Care, 1978). Serum levels of 1,25-dihydroxycholecalciferol are elevated in vitamin D-replete rats given low-P diets (Hughes et al. 1975) and this metabolite of vitamin D is associated with enhanced intestinal $P$ absorption and alkaline phosphatase levels (Peterlik \& Wasserman, 1980). In addition, dietary vitamin D has been shown to stimulate phytase levels in rat intestine (Pileggi et al. 1955; Roberts \& Yudkin, 1961).

Thus, the adaptive increase in phytate-P digestion by rats given low-P diets may be related to an increase in intestinal levels of alkaline phosphatase and phytase mediated by changes in serum levels of 1,25-dihydroxycholecalciferol. The experiment reported here was conducted to determine: (i) the effect of dietary $\mathrm{P}$ level on $\mathrm{Ca}, \mathrm{P}$ and phytate-P utilization in

* Present address: Department of Animal Science, Virginia Polytechnic Institute and State University, Blacksburg, Virginia 24061.

$\uparrow$ For reprints. 
Table 1. Composition $(\mathrm{g} / \mathrm{kg})$ of experimental diets

\begin{tabular}{|c|c|c|}
\hline $\begin{array}{l}\text { Phosphorus level*... } \\
\text { Treatment group... }\end{array}$ & $\begin{array}{l}\text { Marginal } \\
\text { MP }\end{array}$ & $\begin{array}{l}\text { Adequate } \\
\text { AP }\end{array}$ \\
\hline \multicolumn{3}{|l|}{ Ingredients } \\
\hline Ground maize & $714 \cdot 4$ & $712 \cdot 5$ \\
\hline Soya-bean meal $(44 \%)$ & $131 \cdot 2$ & $131 \cdot 2$ \\
\hline Egg albumen $\dagger$ & $14 \cdot 2$ & $14 \cdot 2$ \\
\hline Maize oil & $78 \cdot 0$ & $78 \cdot 0$ \\
\hline Amino acids $\ddagger$ & $41 \cdot 0$ & $41 \cdot 0$ \\
\hline Minerals\| & $5 \cdot 0$ & $5 \cdot 0$ \\
\hline Vitamins§ & $2 \cdot 2$ & $2 \cdot 2$ \\
\hline Calcium carbonate & $11 \cdot 6$ & $9 \cdot 1$ \\
\hline Phytic acid & $0 \cdot 4$ & $0 \cdot 4$ \\
\hline Calcium phosphate, dibasic & - & $4 \cdot 4$ \\
\hline Chromic oxide & $2 \cdot 0$ & $2 \cdot 0$ \\
\hline \multicolumn{3}{|l|}{ Analysed nutrient composition $(\mathrm{g} / \mathrm{kg})$} \\
\hline Crude protein $(\mathrm{N} \times 6.25)$ & $164 \cdot 0$ & $160 \cdot 0$ \\
\hline Total $\mathrm{P}$ & $3 \cdot 0$ & $4 \cdot 0$ \\
\hline Calcium & $5 \cdot 7$ & $6 \cdot 2$ \\
\hline Phytate-P & $1 \cdot 2$ & $1 \cdot 3$ \\
\hline Molar Ca:P & 1.46 & $1 \cdot 20$ \\
\hline Proportion of total $\mathbf{P}$ as phytate-P & 0.400 & 0.325 \\
\hline
\end{tabular}

* Marginal-P level $3 \mathrm{~g} / \mathrm{kg}$, adequate-P level $4 \mathrm{~g} / \mathrm{kg}$ based on recommendations of (US) National Academy of Sciences (1978).

$\dagger$ Spray-dried egg albumen; Kraft Corp., Memphis, Tennessee, autoclaved at $121^{\circ}$ for $20 \mathrm{~min}$.

$\ddagger$ Amino acid supplement provided (g/kg diet): L-glutamic acid 32.1, L-histidine-hydrochloride $0 \cdot 4$, L-lysine-hydrochloride $2 \cdot 1$, DL-methionine $4 \cdot 3$, L-threonine $0 \cdot 7$, L-tryptophan $0 \cdot 6$, L-valine $0 \cdot 8$.

|| Mineral premix provided (/kg diet): $18 \mathrm{mg} \mathrm{Zn}$ as $\mathrm{ZnCO}_{3}, 0.1 \mathrm{mg} \mathrm{Se}$ as $\mathrm{Na}_{2} \mathrm{SeO}_{3} .5 \mathrm{H}_{2} \mathrm{O}, 75 \mathrm{mg} \mathrm{Mn}$ as $\mathrm{MnSO}_{4}$, $0.3 \mathrm{mg} \mathrm{I}$ as $\mathrm{KI}, 2 \mathrm{mg} \mathrm{F}$ as NaF, $0.5 \mathrm{mg} \mathrm{Cr}$ as $\mathrm{CrK}\left(\mathrm{SO}_{4}\right) .12 \mathrm{H}_{2} \mathrm{O}, 16 \mathrm{mg} \mathrm{Fe}$ as $\mathrm{FeSO}_{4} .7 \mathrm{H}_{2} \mathrm{O}, 0.4 \mathrm{~g} \mathrm{NaCl}, 2 \mathrm{~g} \mathrm{~K}$ as $\mathrm{K}_{2} \mathrm{CO}_{3}$.

$\S$ Vitamin premix provided (/ $\mathrm{kg}$ diet): biotin $0.2 \mathrm{mg}$, cyanocobalamin, $100 \mu \mathrm{g}$, pyridoxine-hydrochloride $9 \mathrm{mg}$, thiamin $6 \mathrm{mg}$ as thiamin-mononitrate, riboflavin $5 \mathrm{mg}$, Ca pantothenate $12 \mathrm{mg}$, nicotinic acid $30 \mathrm{mg}$, folic acid $2 \mathrm{mg}$, choline chloride $1000 \mathrm{mg}$, vitamin D $37.5 \mu \mathrm{g}$ as ergocalciferol, vitamin E $20 \mathrm{mg}$ as $\alpha$-tocopherol acetate, vitamin A $3.3 \mathrm{mg}$ as retinyl palmitate, vitamin $\mathrm{K} 100 \mu \mathrm{g}$ as menadione sodium bisulphite complex.

Phytic acid supplied as sodium phytate (Sigma Chemical Co., St Louis, Missouri).

growing rats, and (ii) whether changes in intestinal levels of phytase or alkaline phosphatase are involved in the adaptive increase in phytate digestibility by rats given marginal-P diets.

\section{MATERIALS AND METHODS}

Male weanling rats of the Wistar strain were used in a $28 \mathrm{~d}$ study to investigate the effect of dietary $\mathrm{P}$ level on phytate digestibility and $\mathrm{P}$ utilization and intestinal levels of phytase and alkaline phosphatase. Twenty-four rats were divided into two treatment groups of twelve rats each as follows: adequate $\mathrm{P}$ (diet AP; $4 \mathrm{~g} \mathrm{P} / \mathrm{kg}, 6 \cdot 2 \mathrm{~g} \mathrm{Ca} / \mathrm{kg}$ ) and marginal $\mathrm{P}$ (diet MP; $3 \mathrm{~g} \mathrm{P} / \mathrm{kg}, 5 \cdot 7 \mathrm{~g} \mathrm{Ca} / \mathrm{kg}$ ). The compositions of the diets are given in Table 1 .

Food and deionized water were available ad lib. and food consumption was determined daily. Rats were housed in individual stainless-steel cages for a $21 \mathrm{~d}$ feeding period and then transferred to metabolism cages for a $7 \mathrm{~d}$ balance trial. During the balance trial, separate faeces and urine collections were made twice daily ( 06.00 and 18.00 hours) and frozen $\left(-60^{\circ}\right)$. The daily collections for each rat were pooled over the entire collection period. Faeces were dried $\left(60^{\circ}\right.$ for $24 \mathrm{~h}$ ) and ground in a Wiley Mill (Arthur Thomas Co., Philadelphia, Pennsylvania) to pass a 30 -mesh screen. Feed and faeces were analysed for 
$\mathrm{Ca}$ and $\mathrm{P}$ (Association of Official Analytical Chemists, 1980), phytate-P (Ellis et al. 1977) and chromic oxide (Gherke $e t$ al. 1950). Nutrient digestibilities were determined using $\mathrm{Cr}_{2} \mathrm{O}_{3}$ as an inert digestibility indicator (Kotb \& Luckey, 1972).

After $28 \mathrm{~d}$, rats were killed by decapitation and the serum collected. Serum was analysed for Ca by atomic absorption spectroscopy (Perkin-Elmer Corp., 1971), P by a colorimetric method (Goldenberg \& Fernandez, 1966) and alkaline phosphatase using a test kit (Sigma Chemical Co., St Louis, Missouri) with $\rho$-nitrophenylphosphate as the substrate. The right femur from each rat was removed, trimmed of tissue and defatted by reflux extraction with chloroform-methanol $(2: 1, \mathrm{v} / \mathrm{v})$. The femurs were dried to a constant weight, ashed at $550^{\circ}$ for $18 \mathrm{~h}$ and $\mathrm{Ca}$ and $\mathrm{P}$ contents determined (Association of Official Analytical Chemists, 1980).

Intestinal phytase and alkaline phosphatase activities were determined for eight rats from each treatment according to a modified procedure of Davies \& Flett (1978). Duodenum mucosal scrapings (0-160 $\mathrm{mm}$ distal to the pyloric sphincter) were homogenized in $5 \mathrm{vol}$. $0 \cdot 25 \mathrm{M}$-sucrose, $\mathrm{pH} 7 \cdot 4$, in a Ten-Broeck glass homogenizer with a ground-glass pestle (ten strokes). For phytase determination, $0.1 \mathrm{ml}$ portions of the homogenate were transferred to duplicate tubes containing $3.0 \mathrm{ml} 50 \mathrm{~mm}$-Tris-succinate buffer $(0.5 \mathrm{mM}-\mathrm{Mg}$ ions, $\mathrm{pH} 7.4)$ and equilibrated in a water-bath at $37^{\circ}$. The reaction was initiated by the addition of $0.05 \mathrm{ml}$ $50 \mathrm{~mm}$-sodium phytate and terminated by the addition of $1.0 \mathrm{ml}$ trichloroacetic acid $(200 \mathrm{~g} / 1$; TCA) after $30 \mathrm{~min}$. The amount of phosphate liberated was determined on the supernatant fraction (Fiske \& Subbarow, 1925) after centrifugation. Reagent 'blanks' (no enzyme added) and enzyme 'blanks' (no substrate added) were subjected to the same assay procedures as the samples. The amount of phosphate liberated from the test assays was corrected for phosphate found in the 'blanks'.

For alkaline phosphatase assay, $0.1 \mathrm{ml}$ homogenate was further diluted $(1: 5 \mathrm{v} / \mathrm{v})$ with $0.25 \mathrm{M}$-sucrose, $\mathrm{pH} 7.4$, and $0.2 \mathrm{ml}$ of the diluted homogenate was added to tubes containing $3.0 \mathrm{ml} 50 \mathrm{~mm}$-Tris-succinate buffer. The reaction was started by addition of $0.05 \mathrm{ml}$ $0.3 \mathrm{M}-\beta$-glycerophosphate (sodium salt) and terminated by addition of $1.0 \mathrm{ml}$ TCA after $15 \mathrm{~min}$. The phosphate liberated was determined as described previously.

Protein was determined according to the procedure of Lowry et al. (1951). One unit of enzyme activity was equal to $1.0 \mu \mathrm{mol}$ phosphate liberated $/ \mathrm{h}$ per $\mathrm{mg}$ protein at $37^{\circ}$, $\mathrm{pH} 7 \cdot 4$.

Treatment means for the results were compared using Student's $t$ test (Snedecor \& Cochran, 1980).

\section{RESULTS}

No significant differences in food intake or weight gain were found between groups of rats given the two dietary $\mathbf{P}$ levels. Rats given the marginal-P diet consumed $17 \mathrm{~g}$ food $/ \mathrm{d}$ and gained $6.0 \mathrm{~g} / \mathrm{d}$, while rats given the adequate-P diet consumed $17 \mathrm{~g}$ food $/ \mathrm{d}$ and gained $5.8 \mathrm{~g} / \mathrm{d}$. Femur mineralization was not influenced by treatment (Table 2) since both groups had similar levels of bone ash, $\mathrm{Ca}$ and $\mathrm{P}$.

Rats given the marginal-P diet were hypercalcaemic $(P<0.01)$ and hypophosphataemic $(P<0.05)$ compared to rats given the adequate-P diet. However, serum alkaline phosphatase activity did not differ between the two treatment groups (Table 2).

$\mathrm{Ca}, \mathrm{P}$ and phytate-P absorption and utilization results are given in Table 3. Rats given the marginal-P diet had greater apparent digestibilities of total $\mathrm{P}(P<0.01)$ and phytate-P $(P<0.001)$ compared to rats given the adequate-P diet (Table 3$)$. There was a tendency $(P<0 \cdot 10)$ for $\mathrm{Ca}$ digestibility to be greater in rats given the marginal-P diet.

$P$ absorption and retention were greater $(P<0.05)$ in rats given the adequate-P diet. There was a tendency $(P<0 \cdot 10)$ for the rats given the marginal-P diet to be hypophosphaturic. 
Table 2. Effect of dietary phosphorus level on rat femur mineralization and serum levels of calcium, $P$ and alkaline phosphatase (EC 3.1.3.1)

\begin{tabular}{|c|c|c|c|c|}
\hline & \multicolumn{4}{|c|}{ Dietary treatment group $\dagger$} \\
\hline & \multicolumn{2}{|c|}{ Marginal-P } & \multicolumn{2}{|c|}{ Adequate-P } \\
\hline & Mean & SEM & Mean & SEM \\
\hline \multicolumn{5}{|l|}{ Femur } \\
\hline Wt (mg) & 341 & 7 & 346 & 9 \\
\hline $\operatorname{Ash}(\mathrm{g} / \mathrm{kg})$ & 540 & 3 & 543 & 3 \\
\hline $\mathrm{Ca}(\mathrm{g} / \mathrm{kg})$ & 200 & 2 & 200 & 1 \\
\hline $\mathrm{P}(\mathrm{g} / \mathrm{kg})$ & 102 & 2 & 103 & 1 \\
\hline \multicolumn{5}{|l|}{ Serum } \\
\hline $\mathrm{Ca}(\mathrm{mg} / \mathrm{l})$ & $114^{* *}$ & 2 & 105 & 2 \\
\hline $\mathrm{P}(\mathrm{mg} / \mathrm{l})$ & $70^{*}$ & 2 & 76 & 2 \\
\hline Alkaline phosphatase (i.u.) $\ddagger$ & 217 & 10 & 214 & 12 \\
\hline
\end{tabular}

$\dagger$ For details, see Table 1 .

$\ddagger$ One unit is equal to $1 \mu \mathrm{mol} \rho$-nitrophenol liberated $/ \mathrm{min}$ per 1 .

* $P<0.05, * * P<0.01$.

Table 3. Effect of dietary phosphorus level on the digestibility and utilization of calcium, $P$ and phytate- $P$

\begin{tabular}{|c|c|c|c|c|}
\hline & \multicolumn{4}{|c|}{ Dietary treatment group $\dagger$} \\
\hline & \multicolumn{2}{|c|}{ Marginal-P } & \multicolumn{2}{|c|}{ Adequate-P } \\
\hline & Mean & SEM & Mean & SEM \\
\hline \multicolumn{5}{|l|}{$\mathbf{p}$} \\
\hline Digestibility & 0.591 ** & 0.016 & 0.519 & 0.016 \\
\hline Absorbed (mg/d) & $33 \cdot 7^{*}$ & $1 \cdot 1$ & $38 \cdot 3$ & $1 \cdot 7$ \\
\hline Urinary $(\mathrm{mg} / \mathrm{d})$ & $0 \cdot 36+$ & 0.02 & 0.48 & $0 \cdot 07$ \\
\hline Retained (mg/d) & $33 \cdot 4^{*}$ & $1 \cdot 1$ & $37 \cdot 8$ & $1 \cdot 7$ \\
\hline \multicolumn{5}{|l|}{ Phytate-P } \\
\hline Digestibility & $0.653^{* * *}$ & 0.035 & 0.250 & $0 \cdot 066$ \\
\hline $\begin{array}{l}\text { Phytate derived-P } \\
\text { available }(\mathrm{mg} / \mathrm{d})\end{array}$ & $14 \cdot 8^{* *}$ & 1.0 & $6 \cdot 0$ & $1 \cdot 6$ \\
\hline $\begin{array}{l}\text { Percentage of total } P \\
\text { absorbed as phytate-P }\end{array}$ & $43 \cdot 6^{* *}$ & $2 \cdot 0$ & $14 \cdot 4$ & $3 \cdot 9$ \\
\hline \multicolumn{5}{|l|}{ Calcium } \\
\hline Digestibility & 0.527 & 0.014 & $0 \cdot 481$ & 0.018 \\
\hline Absorbed (mg/d) & $57 \cdot 0$ & $1 \cdot 3$ & $55 \cdot 1$ & $3 \cdot 1$ \\
\hline Urinary $(\mathrm{mg} / \mathrm{d})$ & $14 \cdot 1 * * *$ & $1 \cdot 0$ & 6.0 & 0.7 \\
\hline Retained (mg/d) & $42 \cdot 9 *$ & 0.9 & $49 \cdot 1$ & $2 \cdot 9$ \\
\hline \multicolumn{5}{|l|}{$\mathrm{Ca}: \mathrm{P}$ balance } \\
\hline $\mathrm{Ca}: \mathrm{P}$ absorbed & $1 \cdot 70^{* * *}$ & 0.04 & $1 \cdot 43$ & 0.03 \\
\hline $\mathrm{Ca}: \mathrm{P}$ retained & $1 \cdot 29$ & 0.03 & $1 \cdot 29$ & 0.03 \\
\hline
\end{tabular}

$\uparrow$ For details, see Table 1.

$\ddagger P<0.10, * P<0.05, \quad * * P<0.01, * * * P<0.001$. 
Table 4. Effect of dietary phosphorus level on the amounts of phytase (EC 3.1.3.8) and alkaline phosphatase (EC 3.1.3.1) in the duodenal mucosa of rats

\begin{tabular}{|c|c|c|c|c|}
\hline & \multicolumn{4}{|c|}{ Dietary treatment group $\dagger$} \\
\hline & \multicolumn{2}{|c|}{ Marginal-P } & \multicolumn{2}{|c|}{ Adequate-P } \\
\hline & Mean & SEM & Mean & SEM \\
\hline Phytase* & 3.89 & $0 \cdot 37$ & $3 \cdot 41$ & $0 \cdot 34$ \\
\hline Alkaline phosphatase* & $18 \cdot 39$ & $1 \cdot 50$ & $17 \cdot 92$ & 0.72 \\
\hline
\end{tabular}

* One unit of enzyme activity is equal to $1 \mu \mathrm{mol}$ phosphate liberated/h per mg protein at $37^{\circ}, \mathrm{pH} 7.4$. The substrate for alkaline phosphatase was $\beta$-glycerophosphate and the substrate for phytase was sodium phytate.

$\uparrow$ For details, see Table 1.

Assuming that the disappearance of phytate-P during transit through the gastrointestinal tract reflects absorption, rats given the marginal-P diet absorbed more $(P<0.01)$ phytate-P than did rats given the adequate-P diet. This source of $P$ represented a greater percentage of the total $P$ absorbed $(P<0.01)$ in these rats than in those given the adequate-P diet.

There was no difference in the absolute amounts of $\mathrm{Ca}$ absorbed between treatments. However, compared to rats given the adequate-P diet, those given the marginal-P diet were hypercalciuric $(P<0.001)$ and thus retained less $\mathrm{Ca}(P<0.05)$. The $\mathrm{Ca}$ absorbed: $\mathrm{P}$ absorbed value was greater $(P<0.001)$ in the rats given the marginal-P diet. However, because of hypercalciuria, the $\mathrm{Ca}$ retained : $P$ retained value was similar to that for rats given the adequate-P diet. Therefore, the difference in the two ratios was greater $(P<0.001)$ in rats given the marginal-P diet than in those given the adequate-P diet.

There was no difference between the two groups with respect to the levels of phytase or alkaline phosphatase assayed in mucosal scrapings of the duodenum (Table 4).

\section{DISCUSSION}

Even though the level of $P$ in the marginal-P diet $(3 \mathrm{~g} \mathrm{P} / \mathrm{kg})$ was only $25 \%$ lower than that in the diet containing an adequate level of $\mathrm{P}(4 \mathrm{~g} \mathrm{P} / \mathrm{kg})$ the rats given the marginal-P diet were hypophosphataemic and hypercalcaemic, two conditions signifying a state of $P$ deprivation (Brautbar et al. 1979; Lee et al. 1979). Many animal species adapt to $P$ deficiency by increasing the efficiency of $P$ absorption from the intestine (Fox \& Care, 1978; Lee et al. 1979; Fox et al. 1981). Rats given the marginal-P diet in the present study showed an increase in the efficiency of $\mathrm{P}$ absorbed as reflected by an increase in apparent $\mathrm{P}$ digestibility and a tendency toward enhanced renal conservation of $P$ when compared to the rats given the adequate-P diet.

There was also an increase in phytate digestibility by rats given the marginal-P diet. It is possible that some phytate hydrolysis could have occurred during the interval from when the faeces were voided and collected, however, no attempt was made to determine this in our experiment. If this occurred it probably would not alter the relative differences in phytate digestibility noted between treatments, but would result in an over-estimation of the absolute amounts of phytate-P absorbed. The increase in phytate digestibility by rats given the marginal-P diet is in agreement with previous work (Moore \& Veum, 1982) which found that rats given a diet containing $3.4 \mathrm{~g} \mathrm{P} / \mathrm{kg}$ digested more dietary phytate than rats given a $4 \mathrm{~g} \mathrm{P} / \mathrm{kg}$ diet. It has been suggested that the increase in intestinal $\mathrm{P}$ absorption during $\mathrm{P}$ deficiency may be related to enhanced synthesis of alkaline phosphatase in the intestinal mucosa (Kempson et al. 1979; Birge \& Avioli, 1981). The rat possesses substantial levels 
of intestinal phytase and alkaline phosphatase (Pileggi, 1959; Davies \& Flett, 1978) and acid phytase and acid phosphatase (Ramikrishnan \& Bhandari, 1979). Our results clearly show that there was no difference in the intestinal levels of alkaline phosphatase or phytase between rats given either level of dietary $P$, suggesting that these enzymes do not play a role in the adaptive increase in the digestibility of $P$ or phytate- $P$ in rats given marginal- $P$ diets.

Savage et al. (1964) reported that germ-free chicks were unable to hydrolyse dietary phytic acid. Wise \& Gilburt (1982) found that germ-free rats were unable to digest phytate while conventional rats were able to hydrolyse phytate. Many microbes adapt to low media-P concentrations by increasing the synthesis of alkaline phosphatase (McComb et al. 1979). Shieh et al. (1969) found that the synthesis of acid phosphatase was depressed when inorganic-P was added to the media of the mould Aspergillus ficuum. Our results demonstrate an adaptive increase in phytate digestion by rats given the marginal-P diet which is independent of intestinal levels of phytase and alkaline phosphatase. Thus, we suggest that the adaptation may be manifested by enhancement of phytase or alkaline phosphatase synthesis by the intestinal microflora which are stimulated by a lower level of $P$ in the digesta.

Despite enhanced efficiency of $P$ and phytate- $P$ absorption by rats given the marginal-P diet, $\mathbf{P}$ deprivation was evident. Because of hypercalciuria by rats given the marginal-P diet, these rats retained less $\mathrm{Ca}$ than did rats given the adequate-P diet. Hypercalciuria is characteristic of $P$ deprivation (Lee et al. 1979) and Henry et al. (1979) have suggested that the decrease in the efficiency of $\mathrm{Ca}$ utilization in $\mathrm{P}$-deprived rats is a result of competition between soft tissue and skeletal tissue for P. Henry et al. (1979) also found that Ca retained : $P$ retained values by rats decreased, as the level of $P$ in the diet probably reflects a lower level of $P$ absorbed and retained in these rats compared to the rats given the adequate-P diet. However, the difference between the two ratios may also be a reflexion of absorption of a poorly-utilized source of $P$.

The enzymic degradation of phytate is a step-wise dephosphorylation reaction which produces hydrolysates containing partially-phosphorylated inositols (Greaves et al. 1967; Lim \& Tate, 1973). Fardiaz \& Markakis (1981) found significant amounts of inositol di-and triphosphate in a peanut press cake fermented with a mould phytase. These inositol phosphates are potent inhibitors of rat aortic calcification in vivo and in vitro (Thomas \& Tilden, 1972; Van Den Berg et al. 1972). Moore \& Veum (1982) found that rats which adapted to $\mathrm{P}$ deprivation by increasing phytate digestion and $\mathrm{P}$ absorption were still in a state of $\mathrm{P}$ deprivation, which suggested that the inositol phosphates formed in the intestine during phytate digestion represented an absorbable but poorly utilized form of $P$. Nahapetian \& Young (1980) have suggested that improvements in bone mineralization of rats given diets with phytate containing high levels of Ca may be due to a decrease in phytate digestibility that leads to the absorption of less inositol phosphates.

The lower inositol phosphate esters are not quantitatively measured by methods utilizing ferric ion precipitation of inositol phosphates. Møllgaard (1946) reported that inositol monophosphate and inositol diphosphate were not quantitatively precipitated by iron. DeBoland et al. (1975) found that all myo-inositol phosphates from the di- to the hexaphosphate form iron-precipitable complexes. However, the di- and triphosphate complexes were appreciably soluble and, thus, they may not be determined quantitatively by the method employed in our study.

If substantial levels of the lower inositol phosphate esters were present in the faeces, our procedure may not have quantitatively measured them. Thus we would have over-estimated the values reported for phytate digestibility, phytate-P absorbed and the percentage of the total $\mathrm{P}$ absorbed as phytate-P. Additionally, since the enzymic dephosphorylation of 
inositol hexaphosphate proceeds sequentially, it is possible that this error would be differentially greater in the rats given the marginal-P diet, if the dephosphorylation had progressed substantially past the inositol tetraphosphate step.

In conclusion, it appears that the rat is able to compensate for low dietary levels of $P$ by increasing the digestibility of phytate. The mechanism by which this adaptation occurs is unknown. However, it is clear from our results that intestinal phytase and alkaline phosphatase are not involved. Because signs of $P$ deprivation are still present, the $P$ released from phytate may be in a form which is poorly utilized by the rat and, therefore, suggests that inositol phosphates formed during the enzymic degradation of phytate are absorbed.

This investigation is a contribution of the Missouri Agricultural Experiment Station. Thanks are extended to Joel Fox and Scott Marquardt for care of the animals and for technical assistance, to Dr Boyd L. O'Dell for supplying the animals and facilities and to Dr Philip G. Reeves for advice during the course of the experiment and preparation of the manuscript. The authors acknowledge financial support from Diamond V Mills, Inc., Cedar Rapids, Indiana and the UMC College of Agriculture Honors Program Research Fund.

\section{REFERENCES}

Association of Official Analytical Chemists (1980). Official Methods of Analysis, 13th ed. Washington, DC: Association of Official Analytical Chemists.

Birge, S. J. \& Avioli, R. C. (1981). Am. J. Physiol. 240, E384.

Brautbar, N., Lee, D. B. N., Coburn, J. W. \& Kleeman, C. R. (1979). Am. J. Physiol. 236, E283.

Davies, N. T. \& Flett, A. A. (1978). Br. J. Nutr. 39, 307.

DeBoland, A. R., Garner, G. B. \& O'Dell, B. L. (1975). J. Agric. Food Chem. 23, 1186.

Ellis, R., Morris, E. R. \& Philpot, C. (1977). Analyt. Biochem. 77, 536.

Erdman, J. W. Jr (1979). J. Am. Oil Chem. Soc. 56, 736.

Fardiaz, D. \& Markakis, P. (1981). J. Food Sci. 46, 523.

Fiske, C. H. \& Subbarow, Y. (1925). J. biol. Chem. 66, 375.

Fox, J., Bunnett, N. W., Farrar, A. R. \& Care, A. D. (1981). J. Endocr. 88, 147.

Fox, J. \& Care, A. D. (1978). J. Endocr. 77, 225.

Gherke, C. W., Mayer, D. T., Pickett, E. E. \& Runyon, C. V. (1950). Res. Bull. Univ. of Missouri no. 469.

Goldenberg, H. \& Fernandez, A. (1966). Clin. Chem. 12, 871.

Greaves, M. P., Anderson, G. \& Webley, D. M. (1967). Biochim. biophys. Acta 132, 412.

Henry, Y., Gueguen, L. \& Rerat, A. (1979). Br. J. Nutr. 42, 127.

Hughes, M. R., Brumbaugh, P. F., Haussler, M. R., Wergedal, J. E. \& Baylink, D. J. (1975). Science, N.Y. 190,578 .

Kempson, S. A., Kim, J. K., Northrup, T. E., Knox, R. G. \& Dousa, T. P. (1979). Am. J. Physiol. 237 , E465.

Kotb, A. R. \& Luckey, T. D. (1972). Nutr. Abstr. Rev. 42, 813.

Lee, D. B. N., Brautbar, N., Walling, M. W., Silis, V., Coburn, J. W. \& Kleeman, C. R. (1979). Am. J. Physiol. 236, E451.

Lim, P. E. \& Tate, M. E. (1973). Biochim. biophys. Acta 302, 316.

Lolas, G. M., Palamidis, N. \& Markakis, P. (1976). Cereal Chem. 53, 867.

Lowry, O., Rosebrough, N. J., Farr, A. L. \& Randall, R. J. (1951). J. biol. Chem. 193, 265

McComb, R. B., Bowers, G. N. \& Posen, S. (1979). Alkaline Phosphatase, p. 866. New York: Plenum Press.

Møllgaard, H. (1946). Biochim. J. 40, 589.

Moore, R. J. \& Veum, T. L. (1982). Nutr. Rep. int. 25, 221.

Nahapetian, A. \& Young, V. R. (1980). J. Nutr. 110, 1458.

National Academy of Sciences (1978). Nutrient Requirements of Laboratory Animals, 3rd ed. Washington, DC: (US) National Academy of Sciences.

Perkin-Elmer Corp. (1971). Methods in Atomic Absorption Spectroscopy. Norwalk, CT: Perkin-Elmer Corp.

Peterlik, M. \& Wasserman, R. H. (1980). Horm. Metab. Res. 12, 216.

Pileggi, V. J. (1959). Archs. Biochem. Biophys. 80, 1.

Pileggi, V. J., DeLuca, H. F. \& Steenbock, H. (1955). Archs. Biochem. Biophys. 58, 194.

Ramikrishnan, C. V. \& Bhandari, S. D. (1979). Experientia 35, 994.

Roberts, A. H. \& Yudkin, J. (1961). Br. J. Nutr. 15, 457.

Savage, J. E., Yohe, E. J. M., Pickett, E. E. \& O’Dell, B. L. (1964). Poult. Sci. 43, 420.

Shieh, T. R., Wodzinski, R. J. \& Ware, J. H. (1969). J. Bact. 100, 1161.

Snedecor, G. W. \& Cochran, W. G. (1980). Statistical Methods, 7th ed. Ames, Iowa: Iowa State University Press. 
Taylor, T. G. (1980). In Recent Advances in Animal Nutrition-1979, p. 23 [W. Haresign and D. Lewis, editors]. London: Butterworths.

Thomas, W. C. Jr \& Tilden, M. T. (1972). John Hopkins Med. J. 131, 133.

Van Den Berg, C. J., Hill, L. F. \& Stanbury, S. W. (1972). Clin. Sci. 43, 377.

Wise, A. \& Gilburt, D. J. (1982). Appl. Environ. Microbiol. 43, 753. 